\title{
Rancang Bangun Evaporator Ultrasonik Untuk Produk Sari Kurma yang Bekerja Pada Suhu Rendah
}

\author{
Iyus Hendrawan ${ }^{1 \mathrm{a})}$, Mohamad Haifan ${ }^{2 \mathrm{~b})}$ \\ ${ }^{1}$ Program Studi Teknik Mesin, Institut Teknologi Indonesia \\ Jl. Raya Puspiptek, Serpong, Tangerang Selatan-Banten, Indonesia, 15320 \\ ${ }^{2}$ Program Studi Teknik Mesin Otomotif, Institut Teknologi Indonesia \\ Jl. Raya Puspiptek, Serpong, Tangerang Selatan-Banten, Indonesia, 15320 \\ a)iyushendrawan@yahoo.com (corresponding author), b)haifan63@yahoo.com
}

\begin{abstract}
Abstrak
Sari kurma merupakan makanan tambahan (food supplement) yang dihasilkan dari proses ekstraksi/ pengepresan buah kurma menjadi cairan kental yang siap untuk dikonsumsi. Kandungan gizi dan nutrisinya tidak berbeda dengan kurma. Pada industri skala kecil, pengolahan sari kurma dilakukan melalui proses evaporasi pada suhu tinggi, akibatnya beberapa senyawa penting seperti vitamindan mineralakan terjadi kerusakan, sehingga manfaat sari kurma bagi kesehatan tubuh akan menurun. Teknologi ultrasonik merupakan salah satu metode yang dapat diterapkan pada proses evaporasi yang dikombinasikan dengan suhu rendah, sehingga didapatkan produk sari kurma yang aman dan tidak mengakibatkan degradasi terhadap senyawa penting yang dikandungnya. Tujuan penelitian adalah merancang bangun dan ujicoba evaporator yang bekerja berdasarkan ultrasonik yang dikombinasikan dengan suhu rendah untuk menurunkan kandungan air pada sari kurma. Hasil rancangbangun evaporator ultrasonik mempunyai dimensi tinggi $41 \mathrm{~cm}$, diameter $26 \mathrm{~cm}$ dan kapasitas ruang pengoalahan sebanyak 13 liter. Secara umum, hasil rancang bangun dan ujicoba evaporator elektronik berjalan dengan baik. Dari hasil ujicoba untuk penguapan air (tanpa sari kurma) tercatat laju penguapan air sebesar $275 \mathrm{ml} / \mathrm{jam}$, sedangkan untukpenguapan air dalam sari kurma tercatat laju penguapan air sebesar $87,5 \mathrm{ml} / \mathrm{jam}$. Selain untuk evaporasi sari kurma, evaporator ultrasonic dapat digunakan untuk proses evaporasi bahan pangan lainnya dan juga proses pengolahan bahan pangan lainnya, seperti pasteurisasi dan sterilisasi susu, inkubasi yougurt dan sebagainya.
\end{abstract}

Kata Kunci: evaporator ultrasonik, proses suhu rendah, sari kurma

\begin{abstract}
Palm juice is a supplementary food resulting from the extraction / pressing the palm fruit into a viscous liquid that is ready to be consumed. Nutrient content and nutritional no different with dates. On the small scale industries, palm juice processing is done through the process of evaporation at high temperature, consequently some important compounds such as vitamins and minerals will be damage, so that the benefits of palm juice for health will decrease. Ultrasonic technology is one method that can be applied to the process of evaporation combined with low temperatures, so that the product obtained palm juice is safe and does not lead to degradation of the important compounds it contains. The research objective is to design and test wake evaporator working under ultrasonic combined with low temperatures to evaporate the water content in the palm juice. Results of ultrasonic evaporator design has a dimension of $41 \mathrm{~cm}$ in high, $26 \mathrm{~cm}$ diameter and processing chamber capacity is 13 liters. In general, the results of design and test electronic evaporator goes well. From the test results for the evaporation of water (without a date palm juice) recorded water evaporation rate of $275 \mathrm{ml} / \mathrm{h}$, while the water in the palm juice carrying water evaporation rate of $87.5 \mathrm{ml} / \mathrm{hr}$. In addition to palm juice evaporation, ultrasonic evaporator can be used for evaporative other foodstuffs as well as other food processes, such as pasteurization and sterilization of milk, incubation yougurt etc.
\end{abstract}

Keywords: evaporator ultrasound, low level temperatur process, palm juice

\section{PENDAHULUAN}

Buah kurma (Phoenix dactylifera $L$ ) kaya dengan protein, serat, glukosa, dan vitamin (A, B1,B2,C), biotin, niasin, asam folat dan zat mineral yang sangat dibutuhkan bagi tubuh manusia.Sari kurma adalah produk pangan yang dihasilkan dari proses ekstraksi/ pengepresan buah kurma menjadi cairan kental yang siap untuk dikonsumsi. Kandungan nutrisi dan nilai gizinya tidak berbeda dengan buah kurma. Peningkatan permintaan sari kurma berdampak positif terhadap tumbuhnya industri 
pengolahan dimasyarakat. Sampai saat ini telah banyak berkembang industri pengolahan sari kurma dalam skala kecil dan menengah (UMKM).

Salah satu tahapan proses pengolahan sari kurma adalah evaporasi yang bertujuan untuk menurunkan kandungan air, sehingga didapat hasil akhir berupa konsentrat atau sari kurma. Proses evaporasi biasanya dilakukan pada suhu tinggi yang dapat mengakibatkan kerusakan senyawa penting dalam kurma berupa aroma, kandungan gizi dan vitamin yang tidak tahan terhadap perlakuan suhu tinggi.Para peneliti mengembangkan ide dan inovasi teknologi pengolahan pangan baru yang lebih aman, lebih segar dan menghasilkan kualitas pangan yang lebih baik serta umur simpan yang lebih lama. Dehidrasi atau evaporasi yang berbasis teknologi ultrasonik sangat menjanjikan, karena pegaruh tenaga ultrasonik lebih nyata pada suhu rendah, sehingga akan menurunkan kemungkinan terjadinya degradasi pangan [1].

Metode ultrasonik adalah metode yang menggunakan gelombang ultrasonik yaitu gelombang akustik dengan frekuensi lebih besar dari $16-20 \mathrm{kHz}$ [2] Ultrasonik bersifat non-destructive dan non-invasive, sehingga dapat dengan mudah diintroduksi ke berbagai aplikasi di bidang pengolahan pangan [3]. Beberapa keunggulan aplikasi teknologi ultrasonik dalam pengolahan pangan, diantaranya:

a) proses ultrasonik tidak membutuhkan penambahan bahan kimia dan bahan tambahan lain.

b) proses ultrasonik mudah dan cepat, sehingga lebih murah dan efisien.

c) proses ultrasonik tidak mengakibatkan perubahan secara nyata pada struktur kimia, partikel, dan senyawa-senyawa bahan yang digunakan [4].

Kemampuan ultrasonik untuk menimbulkan efek kavitasi yang diaplikasikan pada produk pangan dipengaruhi oleh karakteristik ultrasonik seperti frekuensi, intensitas, amplitudo, daya, karakteristik produk (seperti viskositas, tegangan permukaan) dan kondisi sekitar seperti suhu dan tekanan [5].

Penelitian ini bertujuan untuk merancang bangun evaporator ultrasonik yang diaplikasikan untuk menurunkan kandungan air sari kurma yang berlangsung pada suhu rendah. Hasil rancang bangun evaporator ultrasonik, selanjutnya dilakukan uji coba dengan beberapa perlakuan. Dari hasil penelitian ini diharapkan evaporator ultrasonic dapat meningkatkan kinerja evaporasi yang lebih cepat tanpa mengakibatkan degradasi kandungan nutrisi dan gizi sari kurma.

\section{TEORI DASAR}

\section{Buah Kurma}

Kurma (Phoenix dactylifera L.) merupakan buah dari tanaman keluarga Arecaceae yang memiliki biji dengan satu lembaga (monokotil). Tanaman ini diduga berasal dari dataran Mesopotamia, Palestina atau sekitar Afrika bagian Utara (Maroko) sekitar 4000 tahun sebelum Masehi dan tersebar ke kawasan Mesir, Afrika Asia Tengah dan sekitarnya sejak 3000 tahun sebelum Masehi.

Buah kurma diketahui mengandung komponen serat terlarut (dietary fiber) yang berkisar antara 9-13\% bergantung kepada kultivar dan asal tumbuhnya [6].
Kandungan serat kasar (crude fiber) di dalam buah kurma berkisar $2.5-4.3 \%$ sesuai dengan tingkat kematangannya [7]. Secara umum, semakin matang buah kurma, kadar glukosa dan fruktosa akan semakin meningkat dan kadar serat kasar cenderung menurun. Kadar sukrosa dan serat terlarut cenderung stabil pada semua tingkat kematangan, kecuali pada tahapan khalal (kadar sukrosa akan meningkat) karena pembentukan daging buah terjadi dengan pesat [6]. Jumlah asupan kalori rata-rata untuk satu buah kurma (8.3g) adalah 23 kalori atau 1,3 - 1,8 kali lebih banyak dibandingkan gula tebu dengan bobot yang sama. Nilai indeks glikemik (GI) dari buah kurma matang tua berada pada kisaran 30-60 jika dikonsumsi sebanyak 60g (sekitar 7 butir ukuran besar). Nilai ini sama dengan nilai GI sukrosa (50g) yang umum dijumpai pada gula tebu [8]. Kandungan total protein pada buah kurma mencapai angka $1.4-1.7 \mathrm{~g} / 100 \mathrm{~g}$ daging kurma (berat basah). Treonin, Lisin dan Isoleusin adalah asam amino esensial (tidak dapat disintensis oleh tubuh) yang ditemukan pada buah kurma [7]. Kadar lemak dari kurma sangat rendah (0.3$0.5 \%$ ), sehingga buah kurma bukanlah makanan terbaik yang menyediakan asupan asam-asam lemak bagi tubuh. Akan tetapi biji kurma memiliki kandungan asam lemak rantai ganda (unsaturated fatty acid). Disebutkan bahwa terdapat Asam Oleat sebanyak $48.5 \mathrm{~g} / 100 \mathrm{~g}$ biji kurma, diikuti dengan Asam Linoleat sebanyak $3.3 \mathrm{~g} / 100 \mathrm{~g}$ biji kurma. Kandungan asam lemak jenuh rantai sedang seperti Laurat, Palmitat, dan Stearat juga cukup mendominasi kandungan nutritif dari biji kurma, dengan total sekitar $40-45 \%$ berat kering [6].

\section{Aplikasi Ultrasonik Dalam Bidang Pangan}

Ultrasonik adalah bentuk energi yang dihasilkan oleh gelombang suara (tekanan) dengan frekuensi sangat tinggi yaitu di atas $16 \mathrm{kHz}$ [9]. Berdasarkan frekuensi yang digunakan dan amplitudo gelombang suara yang diterapkan, sejumlah pengaruh fisik, kimia dan biokimia dapat diteliti, sehingga dapat diterapkan untuk berbagai macam aplikasi [10]. Gelombang ultrasonik dapat merambat dalam medium padat, cair dan gas.Beberapa aplikasi gelombang ultrasonik telah banyak dimanfaatkan di berbagai bidang keilmuan. Di bidang industri, pemanfaatan gelombang ultrasonik dipergunakan untuk pemeriksaan produksi, proses industri, fabrikasi logam dan sebagainya. Di bidang kedokteran, gelombang elektronik frekuensi tinggi digunakan untuk pemindaian medis terkait dengan diagnosis dan pengobatan (terapi) dengan resiko yang kecil.Di bidang pangan, gelombang ultrasonik dikembangkan untuk menentukan kualitas bahan pangan dan hasil pertanian [9].

Salah satu aplikasi metode ultrasonik dalam proses pengolahan pangan adalah proses ekstraksi. Salah satu manfaat metode ekstraksi ultrasonik adalah untuk mempercepat proses ekstraksi [11]. Pada ekstraksi pati jagung yang menyebutkan rendemen pati jagung yang didapat dari proses ultrasonik selama 2 menit adalah sekitar 55,2-67,8\% hampir sama dengan rendemen yang didapat dari pemanasan dengan air selama 1 jam yaitu $53,4 \%$. [12]. Dengan penggunaan ultrasonik proses ektraksi senyawa organik pada tanaman dan biji-bijian dengan menggunakan pelarut organik dapat berlangsung lebih cepat. Dinding sel dari bahan dipecah dengan 
getaran ultrasonik sehingga kandungan yang ada didalamnya dapat keluar dengan mudah [13].

Beberapa keunggulan aplikasi teknologi ultrasonik dalam pada berbagai proses pengolahan pangan [4], diantaranya:

a) proses ultrasonik tidak membutuhkan penambahan bahan kimia dan bahan tambahan lain.

b) prosesnya cepat dan mudah, yang berarti prosesnya tidak memerlukan biaya tinggi.

c) prosesnya tidak mengakibatkan perubahan yang signifikan pada struktur kimia, partikel, dan senyawa-senyawa bahan yang digunakan.

Hal-hal yang mempengaruhi kemampuan ultrasonik untuk menimbulkan efek kavitasi yang diaplikasikan pada produk pangan antara lain karakteristik ultrasonik seperti frekuensi, intensitas, amplitudo, daya, karakteristik produk (seperti viskositas, tegangan permukaan) dan kondisi sekitar seperti suhu dan tekanan [14].

Terdapat beberapa jenis konfigurasi reaktor gelombang ultrasonik antara lain: sistem tanduk getar, batch, rambatan frekuensi ganda, rambatan frekuensi tripple, sistem batch dengan getaran longitudinal, homogenizer tekanan tinggi, homogenizer kecepatan tinggi dan plat orifice [3]. Salah satu sistem ultrasonik yang sering digunakan adalah ultrasonik tanduk getar. Ultrasonik tanduk getar menggunakan gelombang yang ditransmisikan dengan frekuensi $16-30 \mathrm{kHz}$ dengan daya hingga $240 \mathrm{~W}$. Luas penampang iradiasi tergantung dari kedalaman celup tanduk getar dan bisa digunakan untuk mengatur intensitas iradiasi. Konfigurasi ultrasonik sistem tanduk getar ini bisa digunakan untuk kebutuhan merusak jaringan sel tanaman, homogenisasi, dan proses-proses percepatan reaksi kimia [15]. Peralatan ultrasonik sistem tanduk getar terdiri atas generator pembangkit gelombang, tanduk getar, pengatur frekuensi, pengatur amplitudo, dan tanduk getar. Penyangga tanduk getar bisa menggunakan rangka atau statif.Efisiensi pembangkit gelombang ultrasonik jenis ini paling rendah dibandingkan jenis lain yang telah berkembang. Efisiensi rambatan energi dari tanduk getar ke cairan terhadap input total energi berkisar 7,6 persen [15].

\section{METODOLOGI}

\section{Konsep Rancangan}

Pendekatan desain meliputi penentuan Kriteria Disain, Desain Fungsional dan Struktural. Kriteria desain alat evaporator yakni:

1) Proses evaporasi menggunakan temperature kamar

2) Terjadi penguapan air pada produk dengan menggunakan ultra sonik

3) Dilengkapi dengan sistim kontrol temperatur

4) Bahan konstruksi mudah diperoleh dipasaran dan memenuhi syarat untuk pengolahan pangan.

Pada desain fungsional, alat evaporator ini terbagi dalam dua bagian besar yaitu bagian konstruksi dan sirkuit elektronik. Alat evaporator berfungsi untuk melakukan proses evaporasi secara optimal. Bagian konstruksi terdiri atas: a) Tabung dalam

b) Tabung luar

c) Sensor tabung luar

d) Cover penutup

e) Heater

f) Penggetar ultrasonic

Bagian elektronik yang diletakkan dalam box kontrol terdiri atas cirkuit power supply, saklar power, saklar heater, saklar penggetar ultra sonik, temperatur kontrol air, lampu indikator, dan distributor arus listrik

Pendekatan desain struktural alat evaporator ini yakni dengan menggunakan bahan dan komponen yang mudah didapat dipasaran serta dapat dirancang bangun dengan peralatan pendukung yang umumnya ada diperbengkelan dan aman untuk digunakan.

Disain struktural alat pasteurisasi dapat dijelaskan sebagai berikut:

a. Tabung dalam: terbuat dari bahan stainless steel berdiameter $19.5 \mathrm{~cm}$, tinggi tabung $20 \mathrm{~cm}$ dengan total kapsitas produk yang dapat dipasteurisasi 6 liter

b. Tabung luar: terbuat dari bahan stainless steel berdiameter $26 \mathrm{~cm}$, tinggi tabung $30 \mathrm{~cm}$ dengan total kapasitas air sebagai sumber pemanas sebanyak 13 liter

c. Sensor Tabung Luar: jenis sensor CA dengan panjang probe $5 \mathrm{~cm}$, berdiameter $5 \mathrm{~mm}$, panjang kabel probe 1 meter

d. Cover penutup: terbuat dari stainless steel

e. Heater sebagai sumber panas dengan kebutuhan daya sebesar 1000 watt

f. Box kontrol terbuat dari stainless steel dengan bagian depan untuk panel-panel kontrol.

Untuk bagian elektronik dalm Box kontrol yaitu

a. Power supply atau dikenal catu daya mempunyai tegangan AC 24 volt dengan arus 1.2 ampere

b. Kontrol temperatur analog merk EGO mempunyai kemampuan mendeteksi suhu 30 derajat Celsius sampai $110^{\circ} \mathrm{C}$. Pada alat evaporator kontrol temperatur digunakan baik untuk mengontrol temperatur produk.

c. Saklar dilengkapi dengan indikator lampu untuk mematikan dan menghidupkan power utama, heater (pemanas ), kontrol temperatur.

\section{Pengujian}

Prosedur pengujian dimulai dengan penyiapan produk yang akan dievaporator baik dengan menggunakan air maupun sari kurma. Untuk pengujian evaporator menggunakan air dimasukkan $1000 \mathrm{ml}$ air pada tabung dalam dan di set pada temperature kamar, setelah penggetar dinyalakan maka setiap 30 menit diukur penguapan air yang terjadi, hal yang sama dilakukan untuk menguapkan air pada $1000 \mathrm{ml}$ sari kurma.

\section{HASIL DAN PEMBAHASAN}

\section{Hasil Rancang Bangun}

Evaporator Ultrasonik terdiri atas ruang pengolahan (chamber) yang dilengkapi dengan sistem penggetar ultrasonik untuk proses evaporasi suhu rendah. 
Selain itu, Evaporator Ultrasonik juga dilengkapi dengan dengan pemanas (heater) dan kontrol suhu yang dapat digunakan pada pengolahan lainnya, misalnya proses sterilisasi, pasteurisasi bahan pangan, dan yoghurt incubator, seperti ditunjukkan pada Gambar 1.

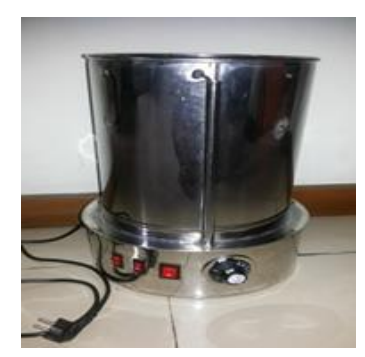

Tampak Samping:

Keseluruhan alat dengan kontrol suhu

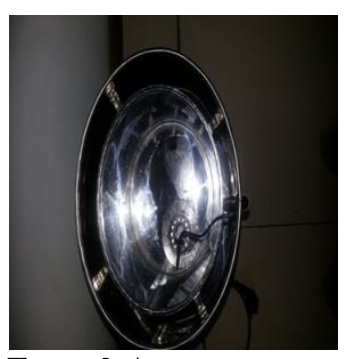

Ruang pengolahan dan penggetar ultrasonik
Tampak Atas:

Gambar 1. Evaporator Ultrasonik

Bagian-bagian dan dimensi Evaporator Ultrasonik hasil rancangan ditunjukkan pada tabel 1.

Tabel 1. Bagian-bagian dan dimensi Evaporator Ultrasonik

\begin{tabular}{|c|c|c|}
\hline No & Uraian & Dimensi \\
\hline 1 & Tinggi keseluruhan & $41 \mathrm{~cm}$ \\
\hline 2 & $\begin{array}{l}\text { Tinggi ruang } \\
\text { pengolahan }\end{array}$ & $30 \mathrm{~cm}$ \\
\hline 3 & Tinggi penyangga & $11 \mathrm{~cm}$ \\
\hline 4 & $\begin{array}{l}\text { Diameter ruang } \\
\text { pengolahan }\end{array}$ & $26 \mathrm{~cm}$ \\
\hline 5 & Diameter penyangga & $31 \mathrm{~cm}$ \\
\hline 6 & Volume chamber & 13 liter \\
\hline 7 & Pemanas (Heater) & 1000 watt \\
\hline 8 & Kec evaporator & $1500 \mathrm{cc} / \mathrm{jam}$ \\
\hline 9 & Diameter ruang proses & $19.5 \mathrm{~cm}$ \\
\hline 10 & Tinggi ruang proses & $20 \mathrm{~cm}$ \\
\hline 11 & Volume ruang proses & 6 liter \\
\hline 12 & Sistem penggetar & $\begin{array}{l}\text { Ultrasonik } 20.000 \\
\text { Hzm } 24 \mathrm{~V} \mathrm{AC}, \\
1200 \mathrm{~mA}\end{array}$ \\
\hline 13 & Set kontrol & $\begin{array}{l}\text { Suhu ruang sampai } \\
100^{\circ} \mathrm{C}\end{array}$ \\
\hline 14 & Komponen lainnya & $\begin{array}{l}\text { Dilengkapi saklar } \\
\text { kontrol, saklar } \\
\text { heater, saklar } \\
\text { penggetar, dan } \\
\text { kontrol suhu }\end{array}$ \\
\hline
\end{tabular}

Cara kerja Evaporator Ultrasonik untuk evaporasi sari kurma:

1) Meletakkan sari kurma yang akan dievaporasi dalam ruang pengolahan (chamber).

2) Penggetar ultrasonik dihidupkan.

3) Proses evaporasi berlangsung pada suhu rendah (suhu kamar), sehingga tidak terjadi kerusakan kandungan gizi dan vitamin yang terdapat dalam sari kurma atau bahan pangan lainnya.

\section{Hasil Pengujian}

Ujicoba Evaporator Ultrasonik dilakukan dengan dua perlakuan, yaitu: a) ujicoba untuk evaporasi air (tanpa sari kurma) dan b) ujicoba untuk evaporasi sari kurma.
Hasil uji coba kedua perlakuan tersebut seperti disajikan pada tabel 2 dan 3.

Tabel 2. Hasil uji coba untuk pengupan air (tanpa sari kurma)

\begin{tabular}{cccc}
\hline No & $\begin{array}{c}\text { Waktu } \\
(\text { menit })\end{array}$ & $\begin{array}{c}\text { Volume Air } \\
(\mathbf{m l})\end{array}$ & $\begin{array}{c}\text { Volume Air } \\
\text { Teruapkan } \\
(\mathbf{m l})\end{array}$ \\
\hline $\mathbf{1}$ & 0 & 1.200 & 0 \\
\hline $\mathbf{2}$ & 30 & 1.100 & 100 \\
\hline $\mathbf{3}$ & 60 & 900 & 200 \\
\hline $\mathbf{4}$ & 90 & 800 & 100 \\
\hline $\mathbf{5}$ & 120 & 650 & 150 \\
\hline
\end{tabular}

Tabel 3. Hasil ujicoba untuk sari kurma

\begin{tabular}{cccc}
\hline No & $\begin{array}{c}\text { Waktu } \\
\text { (menit) }\end{array}$ & $\begin{array}{c}\text { Volume } \\
\text { Sari Kurma } \\
(\mathbf{m l})\end{array}$ & $\begin{array}{c}\text { Volume Air } \\
\text { Teruapkan } \\
(\mathbf{m l})\end{array}$ \\
\hline $\mathbf{1}$ & 0 & 1.000 & 0 \\
\hline $\mathbf{2}$ & 30 & 950 & 50 \\
\hline $\mathbf{3}$ & 60 & 900 & 50 \\
\hline $\mathbf{4}$ & 90 & 875 & 25 \\
\hline $\mathbf{5}$ & 120 & 825 & 50 \\
\hline
\end{tabular}

Pada ujicoba perlakuan pertama untuk penguapan air (tanpa sari kurma) total penguapan air selama 120 menit sebanyak $550 \mathrm{ml}$. Secara rinci dapat dijelaskan bahwa pada 30 menit pertama, 60 menit kedua hingga 120 menit, uap air yang dapat diuapkan berturutturut sebanyak $100 \mathrm{ml}, 200 \mathrm{ml}, 100 \mathrm{ml}$ dan $150 \mathrm{ml}$ seperti ditunjukkan pada tabel 2. Dari hasil tersebut terjadi kecenderungan, semakin lama proses evaporasi, maka laju penguapan air semakin besar.

Pada ujicoba perlakuan kedua untuk penguapan sari kurma, total penguapan air dalam sari kurma selama120 menit tercatat sebesar $175 \mathrm{ml}$. Secara rinci untuk penguapan setiap 30 menit hingga 120 menit, tercatat berturut-turut sebesar $50 \mathrm{ml}, 50 \mathrm{ml}, 25 \mathrm{ml}$ dan 50 $\mathrm{ml}$ seperti pada tabel 3. Laju penurunan uap air pada evaporasi sari kurma cenderung konstan atau sekitar 50 $\mathrm{ml} / 30$ menit.

Selama proses penguapan air tanpa sari kurma dan penguapan air pada perlakuan evaporasi sari kurma ditunjukkan pada gambar 2 dan 3 .
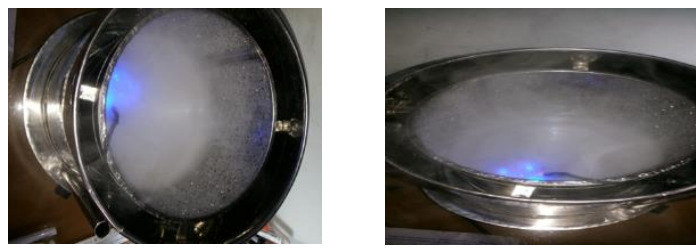

Gambar 2. Selama Proses Penguapan Air
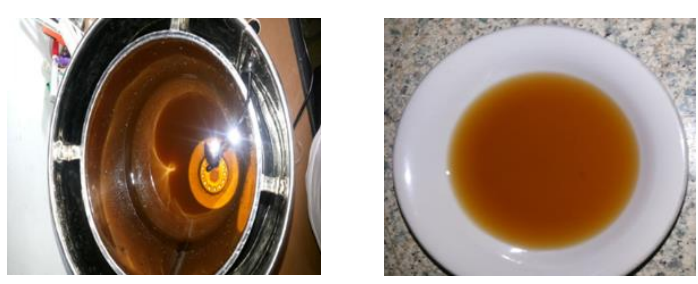

Gambar 3. Selama Proses Penguapan Sari Kurma 


\section{KESIMPULAN}

Hasil rancang bangun dan ujicoba evaporator ultrasonik dapat beroperasi dengan baik. Laju penguapan air (tanpa sari kurma) sebesar $275 \mathrm{ml} /$ jam, sedangkan laju penguapan air pada proses evaporasi sari kurma sebesar $87,5 \mathrm{ml} / \mathrm{jam}$. Evaporator ultrasonik dapat digunakan untuk proses evaporasi bahan pangan lainnya dan juga proses pengoalahan pangan lainnya, seperti pasteurisasi dan sterilisasi susu, inkubasi yoghurt dan sebagainya.

\section{REFERENSI}

[1] Mason, T. J. 1990.Introduction, Chemistry with Ultrasound. Edited by T.J Mason. Elsevier Applied Science.London.

[2] Suslick, K. S. 1988. Ultrasounds: Its Chemical, Physical and Biological Effects. VHC

[3] McClements D.J. 1995. Advances in The Application of Ultrasound in Food Analysis and Processing. Trends Food Sci. Techn. Vol. 6, pp 293-299.

[4] Lida, Y., Tuziuti T., Yasui K., Towata A., and Kozuka T.2002. Control of Viscosity in Starch and Polysaccharide Solution with Ultrasound After Gelatinization. Journal of National Institute of Advanced Industrial Science and Technology (AIST).Nagoya, Japan.

[5] Williams, A.R. 1983. Ultrasound: Biological Effects and Potential Hazards. Academic Press.

[6] Ali, A., Y.S.M. Al-Kindi, and F. Al-Said, 2009.Chemical Composition and Glycemic Index of Three Varieties of Omani Dates. International Journal of Food Sciences and Nutrition, Vol. 60(1 supp 4): pp. 51 - 62.

[7] Al-Farsi, M.A. and C.Y. Lee, 2008. Nutritional and Functional Properties of Dates: A Review. Critical Reviews in Food Science and Nutrition, Vol. 48(10): pp. 877 - 887.

[8] Ahmed, I.A., A.W.K. Ahmed, and R.K. Robinson, 1995. Chemical composition of date varieties as influenced by the stage of ripening. Food Chemistry, Vol. 54(3): pp. 305-309.

[9] Jayasooriya, S.D, Torley, P.J, D'Arcy, B.R and Bhandari, B.R, 2007. Effect of High Power Ultrasound Waves on Properties of Meat : A Review. Int. J. Food Prop, 7.2, pp. 301-319

[10] Knorr, D, Zenker, M, Heinz V and Lee, DU, 2004. Aplication and Potential of Ultrasonic in Food Processing. Trends Food Sci. Techn, Vo. 15, pp. 261-266

[11] Kuldiloke, J. 2002. Effect of Ultrasound, Temperature and Pressure Treatments on Enzyme Activity and Quality Indicators of Fruit and Vegetable Juices. Dissertationder Technischen Universität Berlin. Berlin.

[12] Camarena, F, 2006. Potential of Ultrasound to Evaluate Turgidity and Hydration of The Orange Peel, J. Food Eng, Vol. 75, pp. 503-507

[13] Mason, T.J and Zhao, Y, 1994. Etraction of Tea Solid Using Ultrasound. Ultrasonic Vol. 32 (5), pp. 375-377

[14] Williams, A.R, 1983. Ultrasound: Biological Effects and Potential Hazards. Academic Press

[15] Soesilo, B, 2007. Studi Penggunaan Ultrasonik Untuk Transesterifikasi Minyak. Pengembangan Industri Integratednya. Hotel Senayan Jakarta. SBRC LPPM - IPB Bogor. ISBN 978-979-1312-11-0. 